\title{
RANCANG BANGUN PROTOTIPE SISTEM PENGELOLAAN ARSIP DIGITAL PADA CILEGON CORPORATE SOCIAL RESPONSIBILITY (CCSR)
}

\author{
Arief Herdiansah \\ Program Studi Informatika \\ Fakultas Teknik Universitas Muhammadiyah Tangerang \\ Jl. Perintis Kemerdekaan 1/33 Cikokol Kota Tangerang \\ arief.herdiansah@umt.ac.id
}

\begin{abstract}
CCSR is a non-governmental independent agency that synchronizes and integrates CSR Corporate work programs in Cilegon city with the Cilegon City Medium-Term Development Plan (RPJMD). CSR (Corporate Sense Responsibility) is a company's social responsibility to the environment. This research was conducted at CCSR in order to design prototype of digital records management system. The objective of the research is to prepare a digital document management system design that refers to the process of CSR fund disbursement by CCSR, thus helping CCSR to manage CSR activities effectively, efficiently and accountably. The prototype of the application is built on the development of dashboard design, using the OOAD (Object Oriented analysis and design) model and tested using ISO 9126 testing method. The result of this research is prototype of digital records management system developed into an integrated solution Document Management Systemand can help CCSR to manage they operation document.
\end{abstract}

Keywords: CSR, CCSR, Prototipe, ISO 9126.

\section{PENDAHULUAN}

Menurut UU kearsipan, arsip adalah rekaman kegiatan atau peristiwa dalam berbagai bentuk dan media sesuai dengan perkembangan teknologi informasi dan komunikasi yang dibuat dan diterima oleh lembaga negara, pemerintahan daerah, lembaga pendidikan, perusahaan, organisasi politik, organisasi kemasyarakatan, dan perseorangan dalam pelaksanaan kehidupan bermasyarakat, berbangsa, dan bernegara (UU No 43 tahun 2009 Tentang Kearsipan, pasal 1) ${ }^{[1] .}$

Pada dasarnya arsip dibedakan menjadi arsip dinamis dan statis. Arsip dinamis adalah arsip yang digunakan secara langsung dalam kegiatan pencipta arsip dan disimpan selama jangka waktu tertentu. Sedangkan arsip statis adalah arsip yang dihasilkan oleh pencipta arsip karena memiliki nilai guna kesejahteraan, telah habis retensinya dan berketerangan dipermanenkan yang telah diverifikasi oleh lembaga kearsipan [9].

Untuk dapat memperbaiki permasalahan arsip dengan menggunakan sistem komputerisasi harus memperhatikan beberapa masalah utama dalam proses pengelolaan arsip salinan dan duplikat digital yang jelas, menurut Mary bahwa "sistem pengelolaan arsip digital / DMS harus memiliki fitur untuk mengunggah dokumen, pembuatan metadata (untuk pencarian dokumen) dan membuat pelaporan"[7].

Pertumbuhan jumlah dokumen kertas akan tumbuh seiring dengan kegiatan dari sebuah lembaga, hal ini juga terjadi pada lembaga CCSR, karena dalam menjalankan program CSR, banyak dokumen dibuat dan harus dikelola sebagai dokumen pendukung laporan pertanggungjawaban CCSR kepada perusahaan pemberi dana CSR dan pemerintah kota 
Cilegon. Metode pengelolaan dokumen yangdilakukan saat ini masih konvensional dan belum menggunakan sistem komputerisasi.

Berdasarkan hal tersebut di atas, penulis mengambil penelitian dengan judul: "Rancang

Bangun Prototipe Sistem Pengelolaan Arsip Digital pada CCSR“.

\section{A. Identifikasi Masalah}

Dalam proses pengembangan rancang bangun prototipe arsip digital di CCSR ada bebarapa kendala yang dihadapi:

1. Apakah perusahaan/korporasi yang memiliki sebagian data pengelolaan dana CSR bersedia memberikan data/informasi secara cepat dan tepat untuk keperluan rekapitulasi kegiatan bulanan/tahunan CCSR?

2. Apakah pimpinan penyelenggara pekerjaan penyaluran dana CSR yang dilakukan CCSR bersedia melakukan pelaporan menggunakan sistem?

3. Apakah sudah tersedia data-data penyaluran dan pengelolaan dana CSR oleh CCSR dalam sebuah bank data?

4. Apakah arsip milik CCSR yang ada saat ini disimpan dikelola menggunakan sistem komputerisasi?

5. Apakah sudah disusun pola klasifikasi arsip di CCSR sebagai salah satu metode pengkodean/index dari sebuah arsip?

6. Apakah infrastuktur jaringan komputer, perangkat keras dan perangkat lunak komputer yang dimiliki mendukung implementasi prototipe arsip digital?

7. Apakah manajemen CCSR mendukung implementasi prototipe arsip digital?

\section{B. Batasan Masalah}

Penelitian ini dibatasi dengan batasan sebagai berikut:

1. Pembuatan rancang bangun prototipe arsip digital, sehingga terbentuk sebuh sistem aplikasi yang dapat menjadi alat bantu CCSR dalam mengelola data aktifitas kegiatan yang dilakukan dan membantu manajemen CCSR dalam pengambilan keputusan penyaluran dana CSR yang dikelola dengan executive dashboard yang dihasilkan.
2. Pengujian kualitas prototipe rsip digital dengan pengujian kualitas prototipe berdasarkan ISO 9126, sehingga dihasilkan sebuah sistem dengan kualitas baik dan sesuai dengan kebutuhan pengguna.

\section{Rumusan Masalah}

Permasalahan penelitian dapat dirumuskan sebagai berikut:

1. Bagaimana metode rancang bangun prototipe arsip digital yang dihasilkan dapat menjamin ketersediaan data aktifitas penyaluran dana CSR dan ketersediaan arsip dalam mendukung proses penyaluran dana CSR?

2. Bagaimana pengujian kualitas prototipe executive dashboard arsip digital pengambilan keputusan dengan pengujian kualitas prototipe berdasarkan ISO 9126 dapat membantu dihasilkannya sebuah sistem dengan kualitas baik, sesuai dengan kebutuhan pengguna?

\section{TINJAUAN PUSTAKA}

A. Arsip Digital

Sebuah dokumen dapat dikatakan arsip jika dokumen tersebut mengalamai proses penciptaan oleh orang yang mempunyai wewenang, dikirim dan diterima oleh orang yang berwewenang serta menimbulkan manfaat/kegunaan bagi penerima dokumen tersebut sesuai dengan tujuan dokumen tersebut dibuat, untuk kemudian dokumen tersebut disimpan oleh penerima dalam jangka waktu tertentu sesuai dengan kebutuhan dan peraturan yang berlaku.

Arsip digital adalah arsip yang telah dialih mediakan menjadi format digital (softcopy) dan telah melalui tahapan prosedur proses alih media sebagai mana dijabarkan dalam Peraturan Pemerintah no 28 tahun 2012 tentang pelaksanaan undang-undang no 43 tahun 2009 tentang kearsipan [1].

\section{B. Prototipe}

Model pengembangan sistem prototipe merupakan model pengembangan pengembangan perangkat lunak (software) yang 
dapat dimembuat sistem dikembangkan dengan cara cepat dan sesuai dengan kebutuhan pengguna serta teruji dengan baik karena pengujian terhadap model kerja dari aplikasi baru melalui proses interaksi dan berulangulang. ${ }^{[5]}$

Dari beberapa model pengembangan sistem yang ada, pengembangan sistem model prototipe yang dipilih untuk membangun sistem dalam penelitian ini karena model prototipe merupakan model pengembangan yang terstruktur, sederhana dan cocok digunakan mengembangkan sistem yang baru pertama kali dibuat.

Yasin (2012) menyatakan model prototipe dapat dipakai jika dalam pengembangan sistem dimana ditemukan kondisi, antara lain sebagai berikut:

1. Definisi pengguna bersifat umum, pengguna tidak tahu pasti apa yang diinginkan, definisi pengguna bersifat tidak rinci, pengguna tidak tahu pasti apa dan bagaimana masukan, proses dan keluaran sistem yang dibangun.

2. Pengembang merasa tidak tahu pasti tentang pilihan algoritma yang akan dipakai, bagaimana lingkungan sistem yang akan dikembangkan dan bentuk sifat serta karakteristik antar muka sistem.

3. Terdapat ketidakpastian dipihak pengguna tentang apa yang diinginkan.

4. Terdapat ketidakpastian dipihak pengembang tentang apa yang harus dilakukan [10].

\section{ISO/IEC 9126 - Software Product Quality}

ISO 9126 merupakan sebuah panduan evaluasi standar dari sebuah produk perangkat lunak yang dikeluarkan oleh badan internasional untuk standardisasi. Pada ISO 9126 didefinisikan enam karakteristik yang menggambarkan, mengukur kualitas sebuah perangkat lunak (sistem), yaitu:

1. Kemampuan (functionality) adalah himpunan atribut yang dikenakan pada keberadaan seperangkat fungsi dan sifat mereka yang teleh ditentukan, dibuat untuk memenuhi kebutuhan.

2. Kehandalan (Reliability) adalah himpunan atribut yang dikenakan pada kemampuan perangkat lunak tersebut untuk mempertahankan tingkat kinerja di bawah kondisi tertentu yang dinyatakan untuk jangka waktu tertentu.

3. Kegunaan (Usability) adalah himpunan atribut untuk menjadikan tingkat kualitas dari sistem yang dibangun, seberapa mudah sistem tersebut dipelajari, seberapa mudah digunakan sehingga dapat mendorong pengguna untuk menggunakan sistem tersebut dalam aktifitas pengolahan data dan informasi.

4. Efisiensi (Efficiency) adalah himpunan atribut yang menghubungkan hubungan antara tingkat kinerja perangkat lunak dengan jumlah sumber daya yang digunakan, untuk membuat dan mengoperasikan sistem.

5. Pemeliharaan (Maintenability) adalah set atribut yang diperlukan sebagai probabilitas suatu komponen atau sistem yang mengalami kerusakan dapat dengan mudah diperbaiki atau dipulihan kembali.

6. Portabilitas (Portability) adalah himpunan atribut yang dikenakan pada kemampuan perangkat lunak yang bangun dapat ditransfer dari satu lingkungan ke lingkungan lain [2].

\section{METODOLOGI PENELITIAN}

A. Metode Penelitian

Penelitian ini dilakukan Penelitian ini menerapkan metode penelitian campuran (kuantitatif dan Kualitiatif), dimana pengumpuan data akan dilakukan dengan cara metode survei menggunakan penyebaran daftar peryataan/questioner dan melakukan wawancara/interview langsung ke pihak-pihak yang telah ditentukan.

\section{B. Metode Pemilihan Sampel}

Pemilihan responden sampel yang akan peneliti ikut sertakan dalam proses pengumpulan data/informasi berdasarkan pertimbangan kriteria dengan pertimbangan bahwa sistem digital arsip yang akan diimplementasikan dalam penelitian ini akan digunakan oleh karyawan dan manajemen CCSR untuk memberikan pelayanan kepada 
manajemen CCSR, semua pihak yang berhubungan dan mempunyai hak mengkases dokumen organisasi, maka peneliti menilai sampel yang representatif adalah: manajemen CCSR, Manajemen perusahaan yang mengalolkasikan sebagian dana perusahaan untuk ikut serta dalam program CSR, Staf CCSR dan Masyarakat yang terlibat dan memiliki kepentingan dalam kegiatan CCSR.

\section{Metode Pengumpulan Data}

Metode Pengumpulan data yang dijalankan dalam penelitian ini adalah:

1. Metode Wawancara. Peneliti telah menyiapkan daftar pertanyaan yang berkaitan dengan pengumpulan informasi, apakah pihak-pihak yang terkait dengan sistem

arsip digital (pengelola dan penerima manfaat) dari pengembangan sistem digital.

2. Metode Survey Peneliti telah menyiapkan daftar pertanyaan yang berkaitan dengan pengumpulan informasi dalam bentuk daftar pertanyaan untuk disebarkan kepada pihak-pihak yang terkait (pengelola dan penerima manfaat) dari pengembangan sistem arsip digital CCSR yang sesuai dengan kriteria sample penelitian.

3. Metode Observasi. Observasi atau pengamatan langsung terhadap profil organisasi dan objek penelitian. Teknik observasi dilakukan dengan cara observasi berstruktur yaitu dengan menyiapkan daftar kebutuhan data dan sumber data berkaitan dengan penelitian yang peneliti lakukan. Proses observasi dilakukan untuk mempelajari data-data dari hasil kegiatan yang dilakukan dan dokumen arsip organisasi khususnya yang dikelola oleh CCSR, tujuan dan struktur organisasi, proses bisnis, ketersediaan infrastrukur teknologi, dan kebijakan teknologi informasi yang ada di CCSR.

4. Metode Studi Pustaka. Peneliti mengumpulkan data dengan cara mempelajari, meneliti, dan membaca buku, jurnal, skripsi, Tesis yang berhubungan dengan pengembangan sistem, pengelolaan arsip digital, regulasi pengelolaan arsip yang berlaku di negara Republik Indonesia dan pustaka-pustaka yang berhubungan dengan penelitian yang sedang dilakukan

\section{Instrumentasi Penelitian}

Instrumen yang digunakan untuk penelitian ini adalah peneliti sendiri, tes tulis dan angket kuesioner.

\section{E. Teknik Analisis Data dan Sistem}

Pada proses analisis, teknik analisis yang dilakukan adalah:

1. Analisis data dan sistem pengelolaan arsip berjalan. Analisis dilakukan terhadap prosedur pengumpulan dan pelaporan kegiatan yang dilakukan, pengelolaan arsip yang dihasilkan, sistem pengelolaan arsip, dan pelaporan pengeloaan arsip organisasi CCSR yang sudah berjalan.

2. Analisis Kebutuhan Fungsional, NonFungsional, dan Pengguna. Pemodelan kebutuhan fungsional untuk menggambarkan fungsi sistem dan pengguna yang terlibat serta fungsi-fungsi apa saja yang bisa didapatkan oleh masingmasing pengguna dimodelkan dengan Use Case Diagram.

3. Analisis Perilaku Sistem. Pada tahapan ini, dilakukan analisis perilaku sistem yang dikembangkan dan dimodelkan dengan Activity Diagram dan Sequence Diagram. Perancangan Activity Diagram dan Sequence Diagram disesuaikan dengan situasi dan kondisi pengguna.

\section{F. Langkah-langkah Penelitian}

Dalam penelitian ini, penulis melakukan tahapan penelitian menggunakan model pengembangan sistem prototipe. Langkah penelitian akan melalui beberapa tahapan proses pengerjaan yaitu:

1. Tahap pendahuluan, yaitu tahap dimana peneliti menentukan obyek penelitian dan melakukan identifikasi masalah/kendala yang dihadapi obyek penelitian dalam mengelola data-data operasional dan arsip yang dihasilkan dari kegiatan yang dilakukan serta perbaikan yang dapat diimplementasikan.

2. Tahap analisa kebutuhan, yaitu tahap peneliti melakukan analisa kebutuhan 
pengelolaan arsip kegiatan organisasi secara digital, kebutuhan sebuah arsip digital dari hasil kegiatan dan penyaluran dana CSR dan kebutuhan database rekapitulasi yang mendukung aplikasi pengelolaan arsip.

3. Tahap pengembangan sistem, yaitu tahap peneliti melakukan pengembangan prototipe arsip digital pada CCSR meliputi:

a) analisa prototipe arsip digital pengambilan dengan kebutuhan pengguna.

b) desain prototipe (use case, sequence diagram, statechart) dari prototipe yang akan dibangun.

c) desain (class diagram) dan pembuatan database yang mendukung kebutuhan pengelolaan data yang dapat menghasilkan executive dashboard dan dapat melakukan penyimpanan, pengelololaan asip kegiatan organisasi secara digital.

d) Pembuatan aplikasi/coding prototipe arsip digital.

e) Pengujian prototipe arsip digital, validasi spesifikasi kebutuhan fungsional dan pengujian sistem dengan ISO 9126

f) Implementasi prototipe arsip digital.

\section{ANALISIS DAN PEMBAHASAN}

A. Use Case Sistem Berjalan

Hasil dari tahapan ini peneliti gambarkan dalam bentuk diagram use case dari sistem yang berjalan saat ini seperti terlihat dalam gambar IV.1 berikut ini.

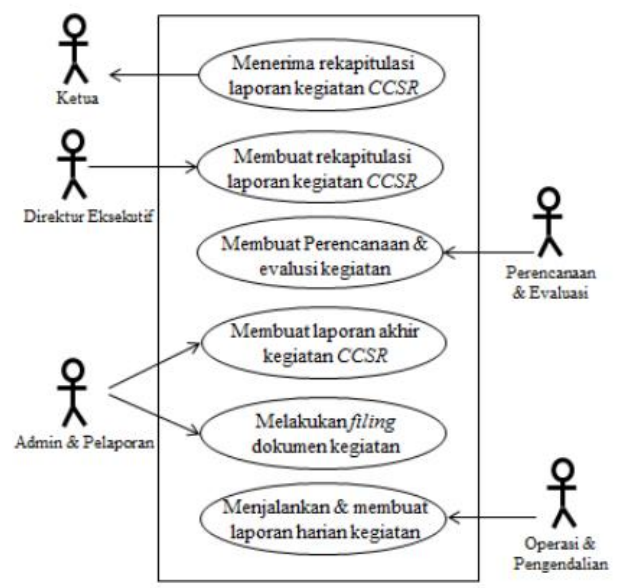

Gambar 1 Diagram use case Sistem Berjalan

\section{B. Diagram Use Case}

Diagram use case menggambarkan alur kerja sistem dalam cara yang sangat sederhana, fungsi utama dari sistem dan berbagai jenis pengguna yang akan berinteraksi dengan sistem, sebagaimana gambar 2 berikut ini:

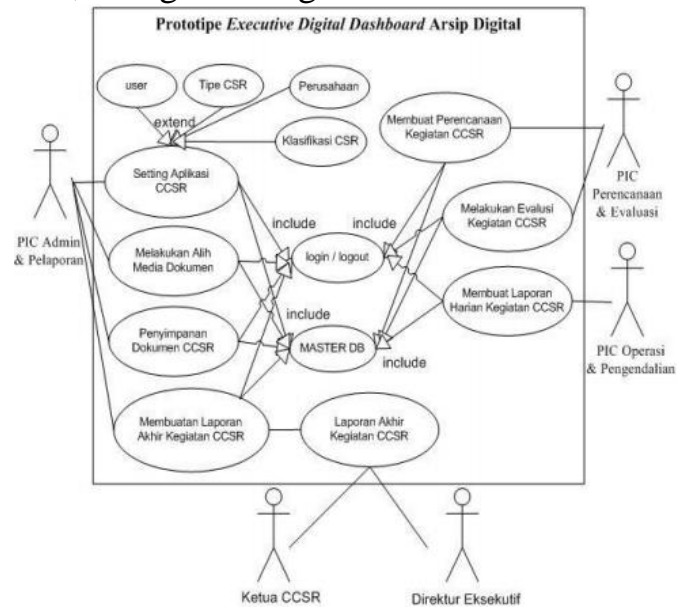

Gambar 2 Diagram use case sistem usulan

\section{Diagram Activity}

Diagram activity merupakan diagram yang menggambarkan worlflow /proses kerja/ atau aktivitas sebuah sistem sebagaimana gambar 3 berikut ini:

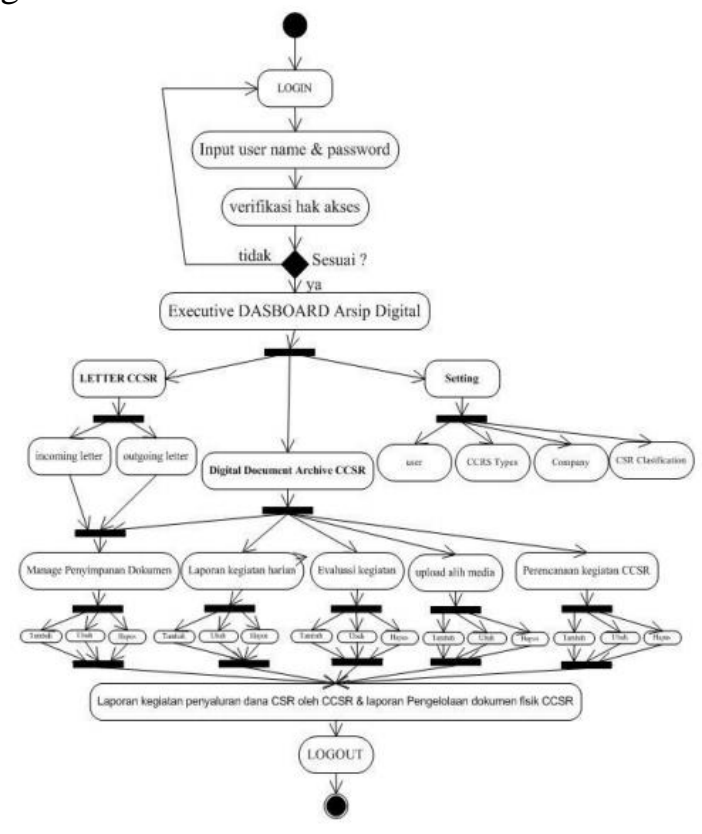

Gambar 3 Diagram Activity 


\section{Diagram Sequence}

Diagram sequence merupakan diagram urutan yang menggambarkan objek yang berpartisipasi dalam use case dan message atau keterangan aktifitas yang dilakukan antaranya dari waktu ke waktu untuk sebuah use case. Diagram sequence merupakan model dinamis yang mendukung tampilan dinamis dari sebuah sistem yang diabngun dan dapat berkembang. Gambar IV.4 menggambarkan diagram sequence dari prototipe arsip digital pada CCSR, dimana terlihat lima actor (PIC Admin \& Pelaporan, PIC Perencanaan \& Evaluasi, PIC Operasi \& Pengendalian, Ketua CCSR dan Direktur eksekutif CCSR) terlibat dalam jalannya sistem yang terdiri dari lima object yaitu login, dashboard, setting, transaction, reporting.

Setiap actor yang ingin mengakses sistem diharuskan memasukan user name \& password dan sistem akan melakukan validasi, apabila actor tersebut diberi hak akses maka dapat mengakses sistem prototipe arsip digital pada CCSR.

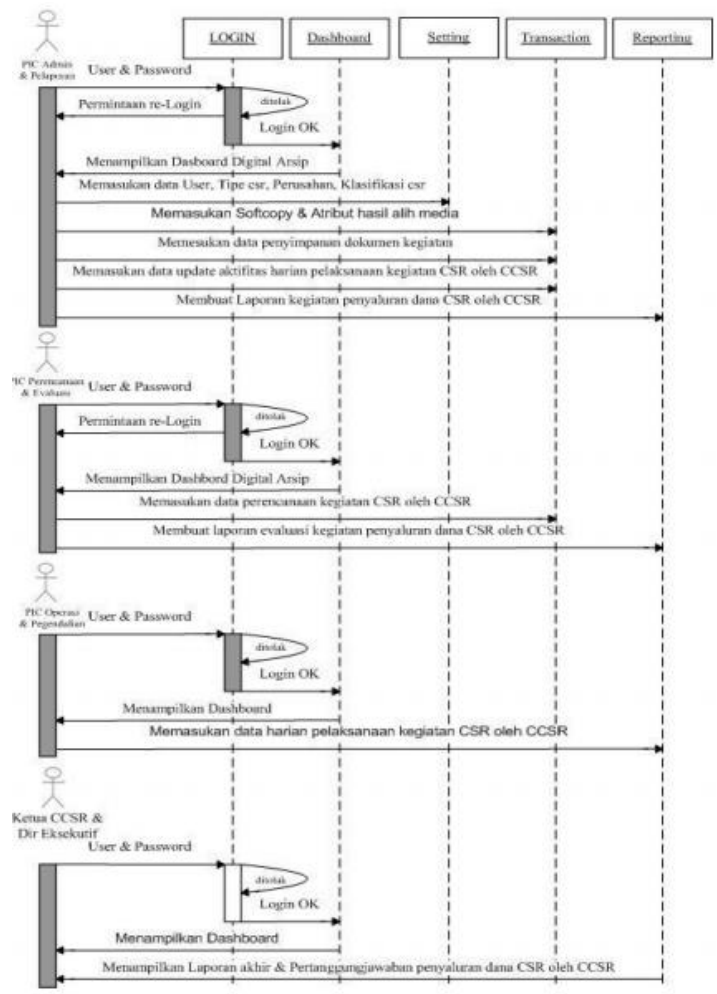

Gambar 4 Diagram Sequence
E. Rancangan GUI

1. Tampilan Menu Utama

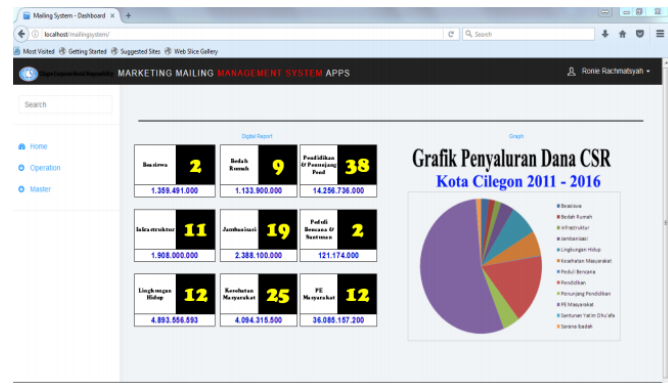

Gambar 5 Tampilan Menu Utama

\section{Tampilan Klasifikasi Arsip}

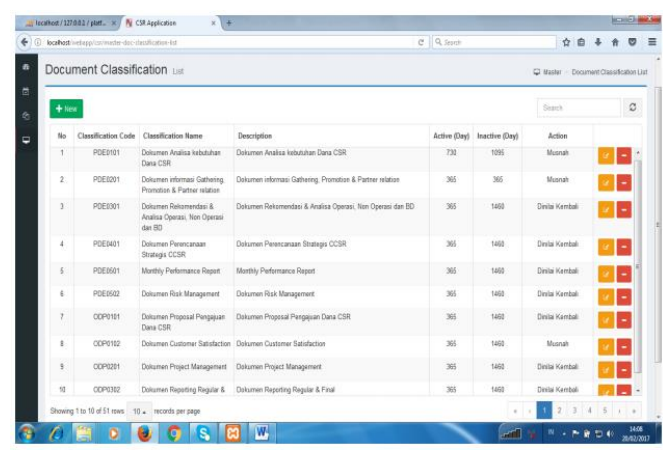

Gambar 6 Tampilan Menu Utama

\section{Tampilan Aktifitas CSR}

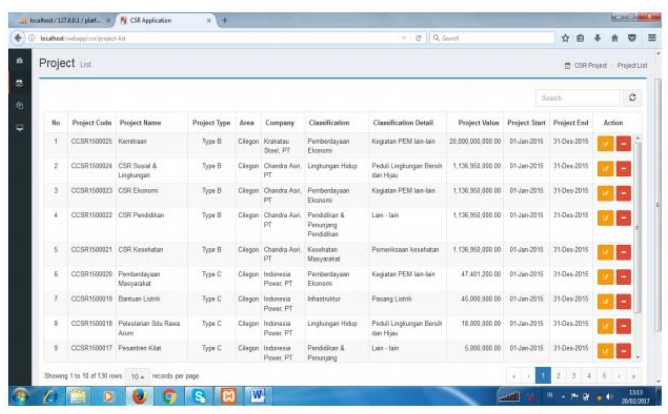

Gambar 7 Tampilan Aktifitas CSR 


\section{Tampilan Upload Arsip Digital}

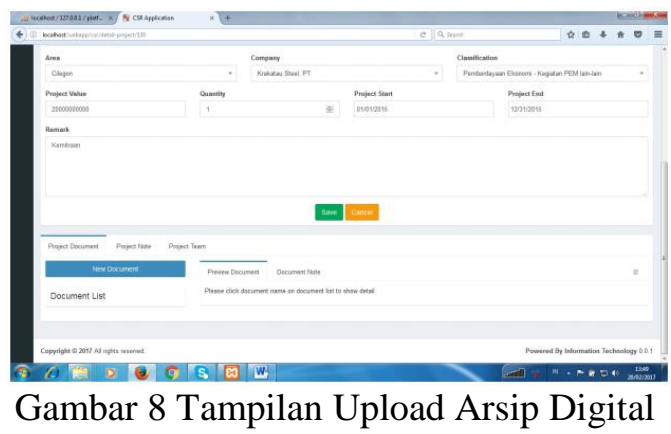

\section{Tampilan Laporan CSR}

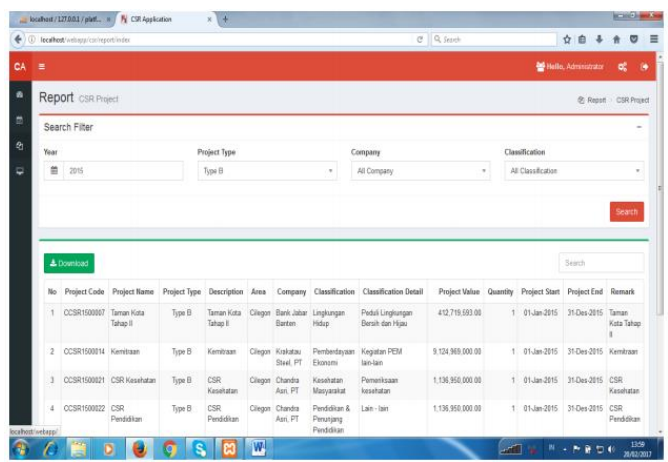

Gambar 9 Laporan CSR

6. Tampilan Dashboard Kegiatan CSR yang Dilakukan CCSR
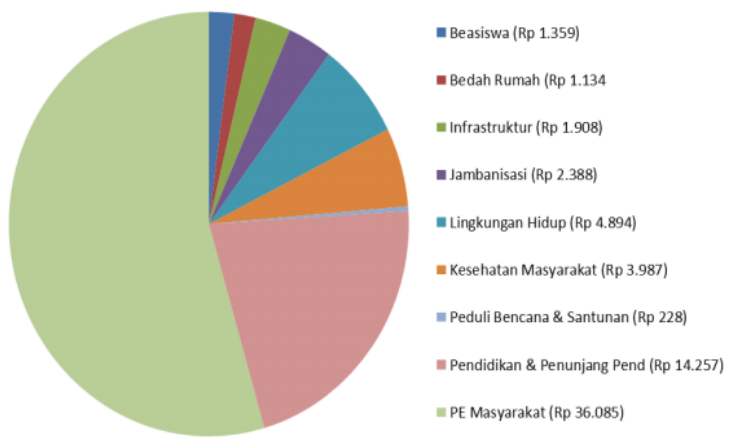

Gambar 10 Tampilan Dashboard

\section{F. Pengujian ISO 9126}

Untuk menilai kualitas sistem berdasarkan enam karakteristik diatas, peneliti membuat formulir user acceptance test yang terdiri 22 peryataan untuk diuji dan dijawab oleh responden/pengguna sistem, sebagaimana Tabel 1 dibawah ini:
Tabel 1 Pengujian ISO 9126

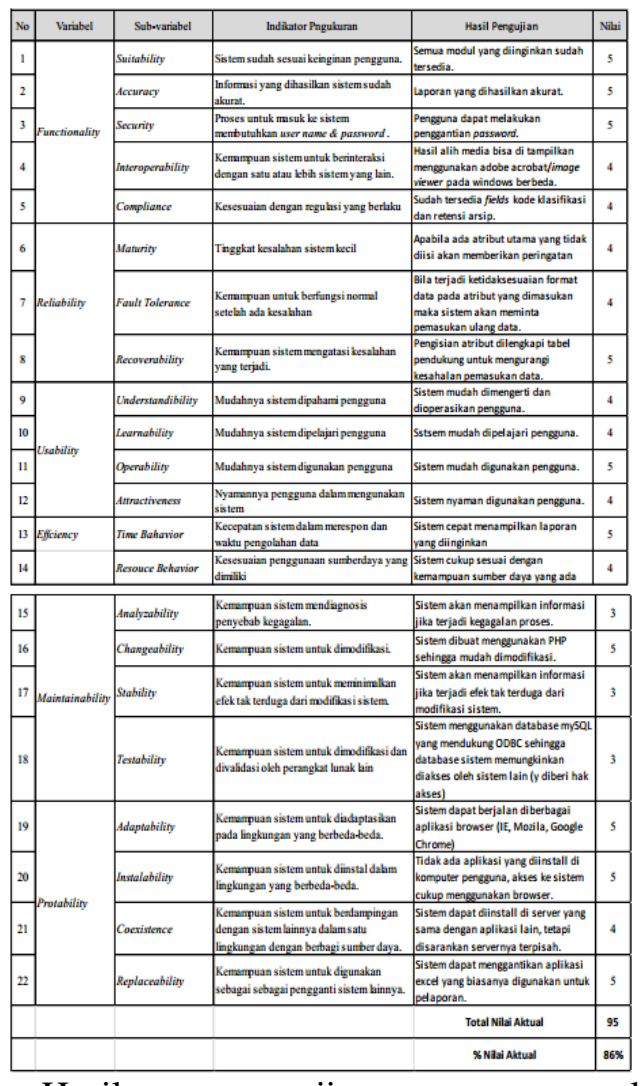

Hasil pengujian menggunakan standarisasi ISO 9126 pengguna yang diberi tugas melakukan pengujian memberikan nilai dengan hasil $\mathbf{8 6 \%}$ (sangat baik).

\section{KESIMPULAN}

Pengembangan prototipe rsip digital di CCSR dapat berfungsi dengan baik ditunjukkan dengan tersedianya kecepatan informasi yang diperoleh dalam bentuk dashboard maupun laporan-laporan kegiatan $C S R$ dalam bentuk tabel yang dapat dicetak, sehingga penyediaan kecepatan layanan informasi yang dibutuhkan dapat diperoleh secara akurat dan effisien. Infomasi yang dihasilkan dari prototipe arsip digital juga dapat digunakan manajemen CCSR sebagai salah satu dasar pengambilan keputusan strategis.

Prototipe arsip digital yang dihasilkan merupakan sistem komputerisasi yang baik, telah teruji kualitasnya dan dapat memenuhi kebutuhan pengguna, proses pengujian prototipe executive dashboard arsip digital 
menggunakan pengujian sistem berdasarkan ISO 9126.

\section{REFERENSI}

[1] ANRI, 2012, Undang-Undang Republik Indonesia Nomor 43 Tahun 2009 Tentang Kearsipan dan PP Republik Indonesia Nomor 28 Tahun 2012 tentang Pelaksanaan UU Nomor 43 Tahun 2009 Tentang Kearsipan. Jakarta, P3K ANRI.

[2] IEC, 2000, International Standard ISO/IEC 9126-1 Information Technology Software Product Quality. https://www.cse.unsw.edu.au/ cs3710/PM materials/ Resources/91261\%20Standard.pdf . Diakses 26 Mei 2016.

[3] Mayer, Holger., Bruder, Ilvio., Finger, Andreas., Heuer, Andreas., Building Digital Archive: Design Decisions. DOI: 10.1109/ ETTLIS.2015.7048172. Date of Conference: 6-8 Jan 2015, IEEE, 2015. http://ieeexplore.ieee.org/document/70481 72/. 2 eptember 2016.

[4] Paul Scifleet, Susan P. Williams, Construction Digital Documents: Emerging Themes in Documentary Practice. System Sciences (HICSS), 44 Hawaii International Conference, IEEE Journal, DOI: 10.1109/HICSS.2011.129, 2011, http://ieeexplore.ieee.org/document/57186 $\underline{041}$

[5] Pressman, S, Roger., 2010, Software Engineering: A Practitioner's Approach, 7th edition. New York, The McGraw-Hill Company.

[6] Putra, Apriyansyah., 2015, Sistem Pengarsipan Elektronik Dokumen Mutu Universitas Sriwijaya. ISSN 1907-4093. Jurnal Generic, Vol $10 \quad$ (1), http://eprints.unsri.ac.id/5692/1/Jurnal_Sis tem_Informasi_Apriansyah.pdf. Diakses 24 Maret 2016

[7] Sengol Mary J, Usha S, 2015, Web Based Document Management System in Life Science Organization. Green Engineering and Technologies (IC-GET), 2015 Online International Conference on, IEEE Journal,
DOI: $\quad$ 10.1109/GET.2015.7453826, http://ieeexplore.ieee.org/document/74538 $\underline{26 /}$

[8] Sergio F. Ocha, Pedro O. Rossel, Maria Cecilia Bastarrica, A Software Architecture to Support Digital Document Interchange for the Cliean Goverment. Advanced Communication Technology, 2006. ICACT 2006. The 8th International Conference, IEEE Journal, DOI: 10.1109/ICACT.2006. 2006441, 2015. http://ieeexplore.ieee.org/document/16260 $\underline{46 /}$

[9] Sugiarto, Agus., Wahyono, Teguh., 2015, Manajemen Kearsipan Modern. Yogyakarta, Gava Media.

[10] Yasin, Verdi., 2012, Rekayasa Perangkat Lunak Berorientasi Objek. Jakarta, Mitra Wacana Media. 